\title{
Rancang Bangun Sistem Monitoring Akademik Program Studi Teknik Informatika Universitas Mataram Menggunakan Data Warehouse
}

\author{
(Design of Academic Monitoring System of Mataram Informatics Engineering Study \\ Program Using Data Warehouse)
}

\author{
Ni Ketut Dewi Febri Wantari, Ario Yudo Husodo, I Wayan Agus Arimbawa \\ Program Studi Teknik Informatika, Fakultas Teknik, Universitas Mataram \\ Jl. Majapahit 62, Mataram, Lombok NTB, INDONESIA \\ Email :wantaridewifebri@gmail.com, ario@ti.ftunram.ac.id, arimbawa@unram.ac.id
}

\begin{abstract}
Informatics Engineering Department (PSTI) has Academic Information System (AIS) which is used for supporting academic operational activities. However, AIS has not been able to provide any information or special report for head and secretary of PSTI. Additionally, the accreditation information referring to the $3 \mathrm{rd}, 4 \mathrm{th}$, and 5 th standard in National Accreditation Board for Higher Education Book VI is not available either. The aim of this system is to help PSTI in providing such information so that the chairman and the secretary can identify the problem of PSTI fastly and accurately. The system is built with Laravel Framework as PHP and JavaScript as its language, and it uses Application Programming Interface (API) in order to integrate it with SIA. Moreover, it uses also data warehouse as an integrated storage. Based on the experimental result, the proposed system has run properly and the system is ready to be used in PSTI.
\end{abstract}

Key words: Monitoring System, Application Programing Interface (API), Data Warehouse.

\section{I.PENDAHULUAN}

Sistem monitoring merupakan sistem yang melakukan pengumpulan dan pemantauan data-data yang dapat dijadikan sebagai dasar dalam pengambilan keputusan oleh top-level management. Pemanfaatan sistem monitoring dalam lingkungan organisasi menjadi kebutuhan tersendiri.

Program Studi Teknik Informatika (PSTI) merupakan salah satu prodi Universitas Mataram (UNRAM) yang berdiri sejak tahun 2012. PSTI memiliki Sistem Informasi Akademik (SIA) dimana sistem ini digunakan untuk menunjang kegiatan operasional akademik dan menyediakan Application Programming Interface (API) yang dapat digunakan untuk pengembangan sistem-sistem yang memerlukan informasi akademik. Akan tetapi SIA ini belum dapat menyajikan informasi atau laporan khusus bagi Ketua dan Sekretaris PSTI.

Proses penyajian informasi masih dilakukan secara manual dan memerlukan waktu yang lama, di mana ketua PSTI terlebih dahulu meminta bagian akademik program studi (prodi) untuk memberikan informasi seputar kegiatan akademik, selanjutnya bagian akademik prodi mengumpulkan data-data yang diperlukan untuk diolah menjadi informasi yang dibutuhkan. Penyampaian informasi disajikan dalam bentuk dokumen atau lisan.

Berdasarkan hasil wawancara dengan Ketua PSTI, kebutuhan informasi PSTI bukan hanya dari data internal SIA, tetapi juga memerlukan informasi dari data-data eksternal yang tersebar. Kebutuhan informasi PSTI terdiri dari kebutuhan informasi berdasarkan akreditasi dan kebutuhan informasi selain akreditasi. Kebutuhan informasi tersebut dibedakan karena, kebutuhan informasi akreditasi menyajikan suatu kesimpulan, bukan hanya menyajikan informasi seperti yang ditampilkan di borang akreditasi. Sedangkan, kebutuhan infromasi selain akreditasi tidak menyajikan suatu kesimpulan. Kebutuhan data dalam menyajikan informasi PSTI terdiri dari kebutuhan data internal dan data eksternal. Pengguaan data warehouse ditujukan untuk mengintegrasikan kebutuhan data tersebut. Hal ini dikarenakan ketika mengakses data pada database normal memerlukan waktu komputasi yang lama, sehingga data warehouse dimanfaatkan sebagai penyimpanan data yang diakses dengan waktu komputasi relative lebih singkat.

Data warehouse merupakan salah satu cara untuk mendapatkan informasi penting dari data internal dan data eksternal yang tersebar serta bersifat readonly. Data-data tersebut dapat disimpan di dalam suatu penyimpanan yang terintegrasi. Data-data yang terintegrasi akan digunakan untuk menyajikan informasi yang dibutuhkan oleh PSTI.

Berdasarkan uraian tersebt, maka pada tugas akhir ini akan dibangun sebuah sistem yang berjudul "Rancang Bangun Sistem Monitoring Akademik Program Studi Teknik Informatika Universitas Mataram Menggunakan Data Warehouse". Judul tersebut dikembangkan untuk membantu PSTI dalam menyajikan kebutuhan informasi PSTI sehingga Ketua dan Sekretaris PSTI dapat 
mengidentifikasi masalah-masalah yang ada di PSTI dengan cepat dan tepat sebagai dasar dalam membuat suatu keputusan.

\section{TINJAUAN PUSTAKA}

Sebelumnya telah banyak dilakukan penelitian yang berkaitan dengan sistem dan data warehouse pada sebuah program studi seperti Prototype Executive Information System untuk Mendukung Evaluasi Diri Perguruan Tinggi (Studi Kasus STMIK Duta Bangsa Surakarta), Sistem Monitoring Dokumen Akreditasi Teknik Informatika UNIKOM, Pembuatan Dashboard berbasis Web Sebagai Sarana Evaluasi Diri Berkala untuk Persiapan Penilaian Akreditasi Berdasarkan Standar Badan Akreditasi Nasional Perguruan Tinggi, dan Perancangan Data Warehouse untuk Sistem Akademik STMIK Kediri.

Sistem Monitoring Dokumen Akreditasi Teknik Informatika UNIKOM dilakukan dengan mengidentifikasi dokumen-dokumen apa saja yang dibutuhkan untuk proses akreditasi. Dokumen yang diidentifikasi berpedoman pada Buku IV (Panduan Pengisian Instrument Akreditasi) dengan menggunakan model database yang dapat menggambarkan keterkaitan antar entitas dalam kegiatan pengumpulan dokumen setiap standar dalam akreditasi. Saran yang diberikan dalam pengembangan sistem ini yaitu adanya proses pengolahan data yang diperlukan dalam sebuah sistem monitoring[1].

Pembuatan Dashboard berbasis Web Sebagai Sarana Evaluasi Diri Berkala untuk Persiapan Penilaian Akreditasi Berdasarkan Standar Badan Akreditasi Nasional Perguruan Tinggi. Aplikasi dashboard yang dibentuk berbasis web dan dikembangkan dengan teknologi Java Server Pages (JSP) dengan tambahan plugin untuk menampilkan komponen dashboard yang berupa grafik, diagram, dan lainnya. Basis data yang dibentuk berisi 64 tabel yang dibagi menjadi sub-sub bagian berbeda, sesuai dengan jumlah pembagian standar penilaian borang akreditasi. Kekurangan dari penelitian ini adalah tidak adanya proses pembentukan data warehouse dan dashboard dikerjakan dalam sistem basis data yang belum terintegrasi dengan baik[2].

Perancangan Data Warehouse untuk Sistem Akademik STMIK Kediri yang membahas masalah perancangan data warehouse serta pengimplementasiannya. Sumber data yang digunakan adalah database akademik STMIK Kadiri. Metode yang digunakan adalah metode penelitian tindakan yaitu menggunakan action research diantaranya tahap Observe, tahap Reflect, Plan dan Act. Hasil dari penelitian ini adalah rancangan data warehouse akademik yang sesuai dengan STMIK Kadiri dan menghasilkan laporan tentang jumlah mahasiswa per angkatan, per jenis kelamin dan per kota asal mahasiswa. Data warehouse ini dibangun dengan SQL Server 2008 dan penyajian data dengan Excel Powerpivot [3].
Prototype Executive Information System untuk Mendukung Evaluasi Diri Perguruan Tinggi (Studi Kasus STMIK Duta Bangsa Surakarta) dengan menggunakan model ServiceOriented Architecture (SOA) yang menyediakan service sehingga mampu menampilkan data dalam bentuk grafik dan tabel yang berfungsi untuk mendukung kegiatan evaluasi diri berdasarkan borang akreditasi BAN-PT tahun 2010. Data diperoleh dengan melakukan proses ETL dengan menggunakan web service dari sistem perguruan tinggi yang ada. Saran yang diberikan dalam penelitian ini yaitu pengembangan hasil analisis yang diberikan dari data yang disajikan dalam bentuk grafik dan tabel[4]. Aplikasi yang mengimplementasikan SOA [5][6] dan API[7][8] juga telah dilakukan dan menghasilkan sistem yang mampu mengambil data dari server lain untuk diolah lebih lanjut.

Berdasarkan uraian penelitian yang dijadikan sebagai rujukan tersebut, maka penulis akan membuat sebuah sistem monitoring PSTI berbasis website menggunakan framework Laravel dengan memanfaatkan teknologi webservice dan data warehouse untuk membantu PSTI dalam menyajikan kebutuhan informasi PSTI yang terdiri dari kebutuhan informasi berdasarkan akreditasi dan kebutuhan informasi selain akreditasi.

\section{III.METODE PERANCANGAN}

Metode perancangan sistem yang dilakukan terdiri dari tahap analisis dan perancangan. Adapun penjelasan tahapan dijelaskan pada sub-bagian berikutnya.

\section{A. Analisis}

Analisis merupakan tahap awal dalam pengembangan sistem monitoring PSTI UNRAM. Proses analisis yang dilakukan yaitu analisis sistem yang sedang berjalan, analisis sistem yang akan dibangun, analisis kebutuhan sistem, analisis kebutuhan service, serta analisis kebutuhan data warehouse. Contoh tahapan analisis kebutuhan sistem dapat dilihat pada Tabel I dan Tabel II.

\section{B. Perancangan}

Proses perancangan yang dilakukan yaitu perancangan arsitektur sistem, perancangan web service client, perancangan arsitektur data warehouse, perancangan model data dimensional, perancangan diagram, dan perancangan tampilan sistem. Beberapa contoh dari perancangan yang dilakukan yaitu perancangan arsitektur sistem yang dapat dilihat pada Gambar 1.

TABLE I. Sumber data terdiri dari data internal SIA yang diperoleh dengan menggunakan API yang disediakan prodi, dan data eksternal yang terdiri dari data eksternal akademik prodi dan Fakultas Teknik. Implementasi aplikasi yang memanfaatkan API SIA Unram telah sukses dilakukan sebelumnya dengan menggunakan prinsip REST API[7]. Data yang diambil 
TABLE II. ANALISIS KEBUTUHAN SISTEM BERDASARKAN AKREDITASI

\begin{tabular}{|l|l|}
\hline No. & \multicolumn{1}{|c|}{ KPI } \\
\hline 1. & $\begin{array}{l}\text { Rasio calon mahasiswa yang ikut seleksi : daya } \\
\text { tampung. }\end{array}$ \\
\hline 2. & $\begin{array}{l}\text { Rasio mahasiswa baru reguler yang melakukan } \\
\text { registrasi : calon mahasiswa baru reguler yang lulus } \\
\text { seleksi. }\end{array}$ \\
\hline 3. & $\begin{array}{l}\text { Rasio mahasiswa baru transfer terhadap mahasiswa } \\
\text { baru bukan transfer. }\end{array}$ \\
\hline 4. & $\begin{array}{l}\text { Persentase mahasiswa yang DO atau mengundurkan } \\
\text { diri. }\end{array}$ \\
\hline 5. & Persentase kelulusan tepat waktu. \\
\hline 6. & Rata-rata Indeks Prestasi Kumulatif (IPK). \\
\hline 7. & Dosen tetap ber-pendidikan terakhir S2 dan S3. \\
\hline 8. & Dosen tetap ber-pendidikan S3. \\
\hline 9. & $\begin{array}{l}\text { Dosen tetap yang memiliki jabatan lektor kepala dan } \\
\text { guru besar. }\end{array}$ \\
\hline 10. & $\begin{array}{l}\text { Dosen yang memiliki sertifikat } \\
\text { profesional. }\end{array}$ \\
\hline 11. & Rasio mahasiswa terhadap dosen. \\
\hline 12. & Rata-rata banyaknya mahasiswa per dosen PA \\
\hline 13. & $\begin{array}{l}\text { Persentase mata kuliah dilengkapi dengan silabus } \\
\text { dan SAP. }\end{array}$ \\
\hline 14. & $\begin{array}{l}\text { Persentase mata kuliah yang memiliki komponen } \\
\text { tugas lebih dari 20\%. }\end{array}$ \\
\hline
\end{tabular}

TABLE III. ANALISIS KEBUTUHAN SISTEM SELAIN KEBUTUHAN AKREDITASI.

\begin{tabular}{|l|l|}
\hline No & \multicolumn{1}{|c|}{ KPI } \\
\hline 1. & Evaluasi DO \\
\hline 2. & Jumlah mahasiswa dengan kategori IPK \\
\hline 3. & Jumlah mahasiswa berdasarkan status kuliah \\
\hline 4. & Jumlah mahasiswa aktif per tahun akademik \\
\hline 5. & Jumlah mahasiswa menyelesaikan Tugas Akhir I \\
\hline 6. & Jumlah mahasiswa menyelesaikan Tugas Akhir II \\
\hline 7. & Jumlah mahasiswa mendapatkan beasiswa \\
\hline 8. & Jumlah mahasiswa mengikuti student exchange \\
\hline 9. & Jumlah mahasiswa mengikuti event tertentu \\
\hline 10. & Prestasi mahasiswa \\
\hline
\end{tabular}

pada SIA terdiri dari data mahasiswa, data dosen, data mata kuliah, data nilai, data tahun akademik, dan data dosen pengajar. Sedangkan, data eksternal yang digunakan terdiri dari data beasiswa, data prestasi, data mahasiswa baru, dan data alumni. Selanjutnya sumber data tersebut dilakukan proses extract (memilih data yang dibutuhkan), transform ( merapikan data dan memperbaiki nama field), dan load (memindahkan data) atau dikenal dengan proses ETL untuk mendapatkan data sesuai dengan kebutuhan sistem. Proses ETL pada data SIA dilakukan dengan menekan sebuah tombol, di mana proses pemindahan dan pengkalkulasian data dilakukan. Setelah proses ETL, data tersebut akan disimpan dalam penyimpanan data warehouse. Data yang tersedia pada data warehouse digunakan untuk menampilkan informasi dalam sistem monitoring yang dapat dilihat oleh administrator dan ketua/sekretaris PSTI.

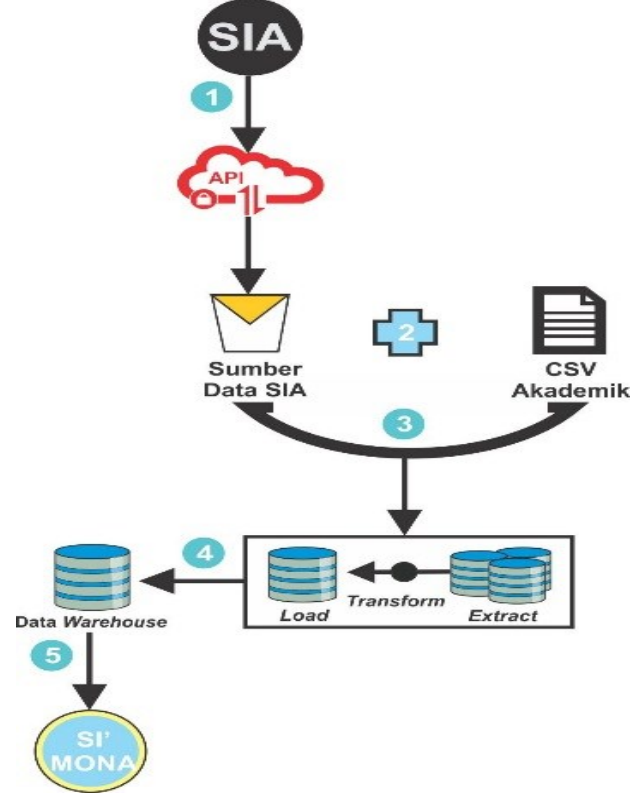

Gambar 1. Rancangan arsitektur sistem monitoring.

\section{IV.HASIL DAN PEMBAHASAN}

Pada bab ini akan membahas mengenai hasil dari penelitian Sistem Monitoring Akademik Menggunakan Data Warehouse berupa proses ETL, implementasi data warehouse, implementasi web service, implementasi sistem, dan hasil pengujian sistem.

\section{A. Proses ETL (Extract, Transform, Load)}

Proses extract merupakan proses memilih data-data bermanfaat yang dibutuhkan untuk memberikan informasi kepada ketua/sekretaris, dan administrator PSTI. Gambar 2 merupakan salah satu hasil extract database operasional SIA.

Pada proses extract data sebelum (a) memiliki 22 field pada tabel mahasiswa. Sementara itu, setelah dilakukan proses extract hanya digunakan 10 field yang bermanfaat.

\begin{tabular}{|c|c|}
\hline $\begin{array}{l}\text { Mahasiswa } \\
\text { nim } \\
\text { nama } \\
\text { jenjang } \\
\text { shift } \\
\text { tempat_lahir } \\
\text { tgl_lahir } \\
\text { jns_kelamin } \\
\text { kode_agama } \\
\text { alamat } \\
\text { kode_provinsi } \\
\text { kode_provinsi_asal_sma }\end{array}$ & $\begin{array}{l}\text { Mahasiswa } \\
\text { nim } \\
\text { nama } \\
\text { jk } \\
\text { status_kuliah } \\
\text { jenjang } \\
\text { shift } \\
\text { tahun_masuk } \\
\text { status_bayar } \\
\text { status_masuk } \\
\text { kode_dosen }\end{array}$ \\
\hline $\begin{array}{l}\text { tgl_masuk } \\
\text { tgl_lulus } \\
\text { thn__masuk } \\
\text { semester_awal } \\
\text { batas_studi } \\
\text { status_kuliah } \\
\text { id_konsentrasi } \\
\text { status_bayar } \\
\text { status_masuk } \\
\text { foto__osen } \\
\text { kode_dosen }\end{array}$ & (b) \\
\hline (a) & \\
\hline
\end{tabular}

Gambar 2. Data sebelum (a) dan sesudah (b) di extract.

Proses transform dilakukan dengan merapikan data, memperbaiki nama field yang digunakan, dan memilih 
kolom-kolom tertentu unuk dimasukkan ke dalam data warehouse. Gambar 3 merupakan salah satu hasil transform yang dilakukan.

Pada proses transform data sebelum (a) memiliki nama field kode dan nama pada tabel dosen. Sementara itu, setelah dilakukan proses transform nama field tersebut diubah menjadi kode_dosen dan nama_dosen.

\begin{tabular}{|l|l|}
\hline Dosen & Dosen \\
\hline $\begin{array}{l}\text { kode } \\
\text { nama }\end{array}$ & kode_dosen \\
NIP & nama_dosen \\
NIDN & nip \\
kode_jabatan & nidn \\
kode_golongan & kode_jabatan \\
kode_pendidikan_tertinggi & kode_pendidikan \\
akta_sertifikat_mengajar & akta_sertifikat \\
& \multicolumn{1}{c}{ (a) } \\
\hline
\end{tabular}

Gambar 3. Data sebelum (a) dan sesudah (b) di transform.

\section{B. Implementasi Data Warehouse}

Sistem ini mengolah seluruh data akademik baik data historis dan data aktif. Namun, data aktif tersimpan dalam keadaan normal. Misalnya, proses perhitungan IPK dilakukan dengan melakukan join antar tabel terlebih dahulu. Oleh sebab itu, untuk menampilkan kebutuhan informasi jumlah mahasiswa berdasarkan kategori IPK pengimplementasian query menjadi lebih rumit dan membutuhkan waktu yang lebih lama. Hal tersebut diatasi dengan membuat temporary warehouse terhadap data aktif. Perbedaan penerapan data warehouse pada sistem ini dengan menggunakan database normal adalah data warehouse menyimpan data dalam keadaan denormalisasi. Penggunaan data warehouse juga ditujukan untuk mengintegrasikan data internal SIA dan data eksternal akademik ke dalam suatu penyimpanan yang terintegrasi.

\section{Implementasi Web Service}

Item-item yang diperlukan untuk implementasi web service dapat diuraikan pada Tabel IV.

\section{Implementasi Sistem}

Pada implementasi sistem terdapat beberapa kategori halaman pada sistem yang dibangun antara lain halaman beranda, halaman informasi berdasarkan akreditasi, halaman informasi selaian akreditasi, dan halaman resume penilaian akreditasi. Halaman beranda administrator pada Gambar 4. terdiri dari tombol load data warehouse yang digunakan untuk mengambil data yang dibutuhkan dari SIA, sedangkan tombol upload digunakan untuk meng-uploadfile csv akademik berdasarkan kategori yang dipilih. Sedangkan, halaman beranda ketua/sekretaris PSTI pada Gambar 5., Gambar 6., Gambar 7., dan Gambar 8.terdapat informasi mengenai mahasiswa dan dosen.
TABLE IV. ANALISIS KEBUTUHAN SERVICE.

\begin{tabular}{|c|c|c|}
\hline No. & Analisis Service & Link \\
\hline 1. & $\begin{array}{l}\text { Service untuk mengambil } \\
\text { data pribadi mahasiswa dan } \\
\text { pembimbing akademik } \\
\text { berdasarkan prodi. }\end{array}$ & students/id/ $/$ NIM $\}$ \\
\hline 2. & $\begin{array}{llr}\text { Service } & \text { untuk mengambil } \\
\text { data } & \text { pribadi } & \text { dosen } \\
\text { berdasarkan prodi. } & \end{array}$ & $\begin{array}{l}\text { lecturers/deptId/\{kode_pr } \\
\text { ogram_studi }\}\end{array}$ \\
\hline 3. & $\begin{array}{l}\text { Service untuk mengambil } \\
\text { data mata kuliah berdasarkan } \\
\text { prodi. }\end{array}$ & courses/dept $/\{$ dept $\}$ \\
\hline 4. & $\begin{array}{l}\text { Service untuk mengambil } \\
\text { data tahun akademik. }\end{array}$ & $\begin{array}{l}\text { classes } /\{\mathrm{TA}\} /\left\{\mathrm{NIP} \_ \text {dose }\right. \\
\mathrm{n}\}\end{array}$ \\
\hline 5. & $\begin{array}{l}\text { Service untuk mengambil } \\
\text { data mata kuliah serta nilai } \\
\text { yang diperoleh mahasiswa } \\
\text { berdasarkan nim dan tahun } \\
\text { akademik. }\end{array}$ & credits/studentId/ $\{\mathrm{NIM}\}$ \\
\hline 6. & $\begin{array}{l}\text { Service untuk mengambil } \\
\text { data matakuliah berdasarkan } \\
\text { mata kulah dan tahun } \\
\text { akademik }\end{array}$ & $\begin{array}{l}\text { classes } /\{\mathrm{TA}\} /\left\{\mathrm{NIP} \_ \text {dose }\right. \\
\mathrm{n}\}\end{array}$ \\
\hline
\end{tabular}

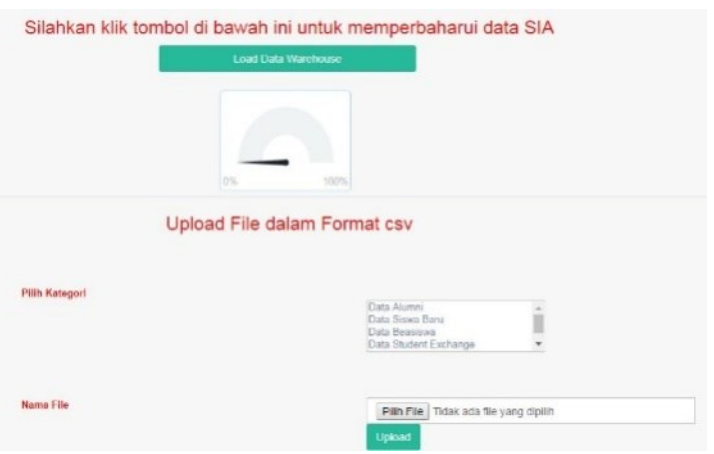

Gambar 4. Halaman beranda administrator.

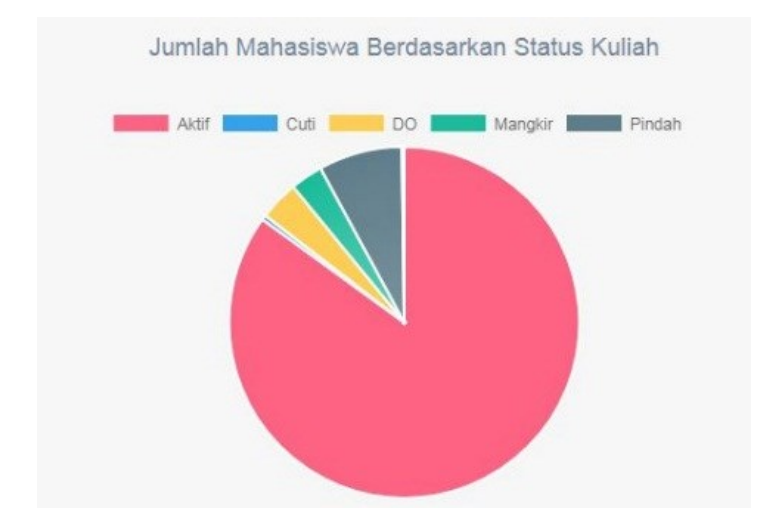

Gambar 5. Halaman beranda ketua/sekretaris PSTI jumlah mahasiswa berdasarkan status kuliah. 


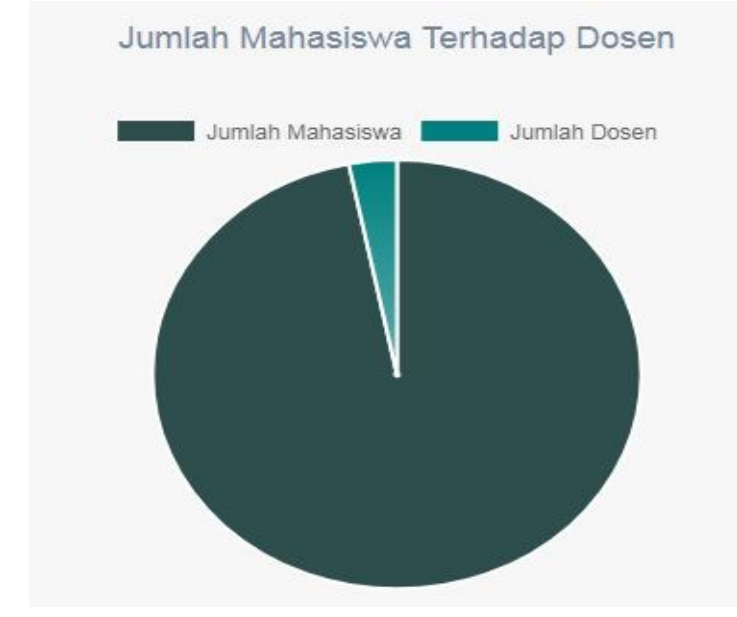

Gambar 6. Halaman beranda ketua/sekretaris PSTI jumlah mahasiswa terhadap dosen.

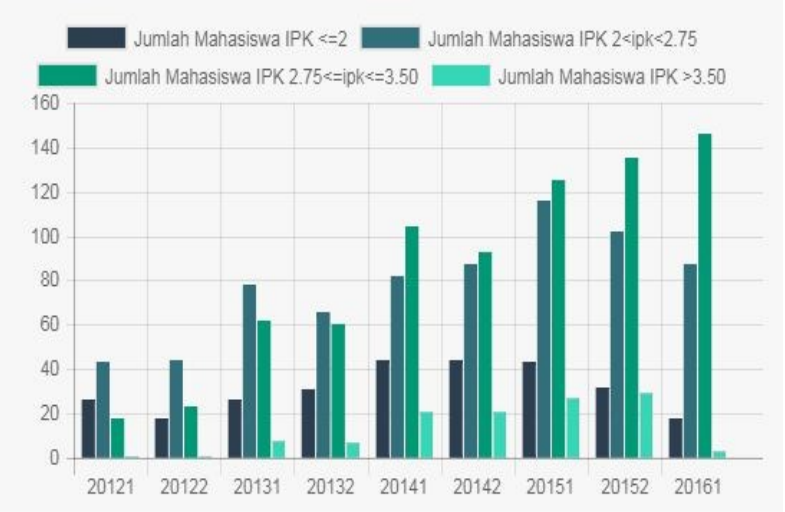

Gambar 7. Halaman beranda ketua/sekretaris PSTI jumlah mahasiswa berdasarkan kategori IPK.

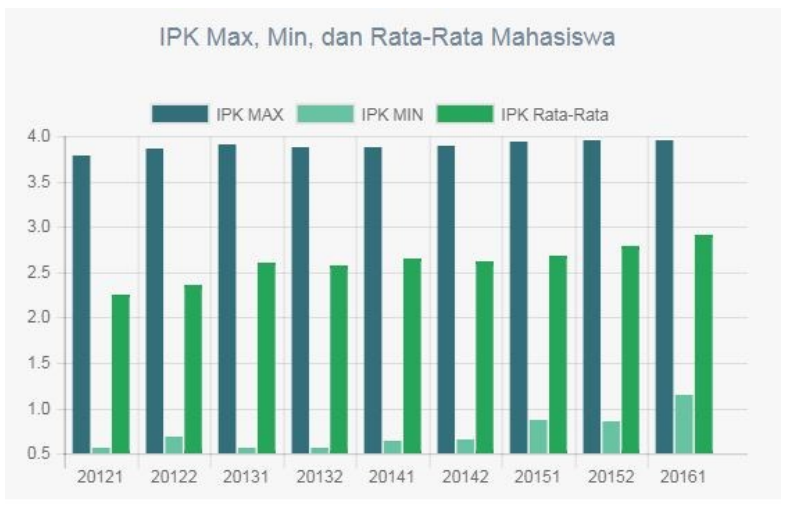

Gambar 8. Halaman beranda ketua/sekretaris PSTI IPK max, min, dan rata-rata mahasiswa.

Halaman informasi berdasarkan akreditasi dapat dilihat pada Gambar 9. dan Gambar 10.dengan contoh penerapan mengikuti standar 3 (Mahasiswa dan Lulusan) poin rasio calon mahasiswa yang ikut seleksi dibagi daya tampung.

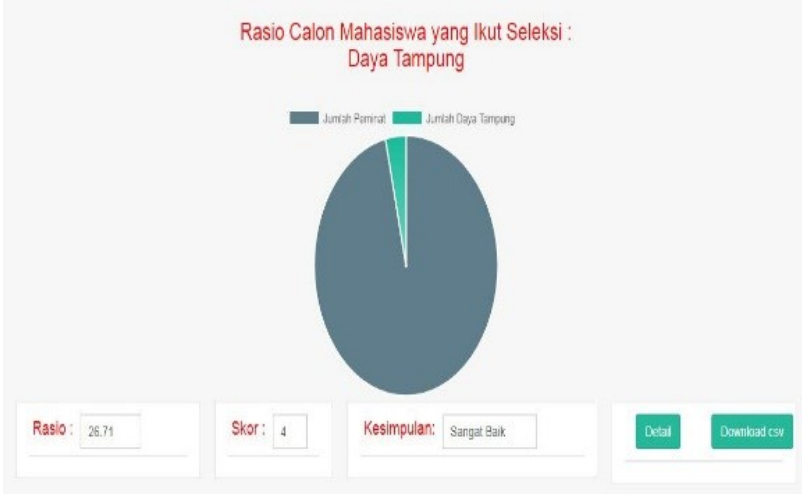

Gambar 9. Halaman informasi berdasarkan akreditasi.

Pada halaman ini terdapat informasi jumlah calon mahasiswa yang ikut seleksi dan jumlah daya tampung selama 5 tahun terakhir dan informasi nilai dari suatu kriteria yang terdiri dari rasio, skor, dan kesimpulan. Teknik perhitungan yang dilakukan untuk mendapatkan nilai tersebut dapat dilihat pada Buku VI (Matriks Instrumen Penilaian Areditasi BAN-PT)[9][10]. Selain itu, pada halaman ini terdapat tombol detail yang digunakan untuk melihat detail dari data tersebut setiap tahunnya dan download csv yang digunakan untuk mendownload data tersebut.

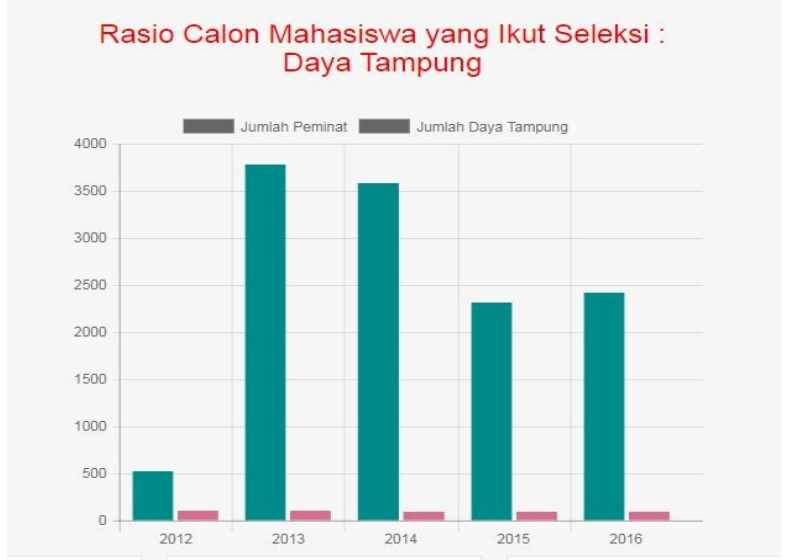

Gambar 10. Halaman informasi detail.

Halaman informasi selain akreditasi dapat dilihat pada Gambar 11 dengan contoh jumlah mahasiswa berdasarkan kategori IPK. Pada halaman ini terdapat tombol detail yang digunakan untuk melihat data mahasiswa berdasarkan kategori IPK dan tahun yang dipilih. Selain itu, halaman ini juga dilengkapi dengan tombol download csv yang digunakan untuk mendownload data tersebut. 


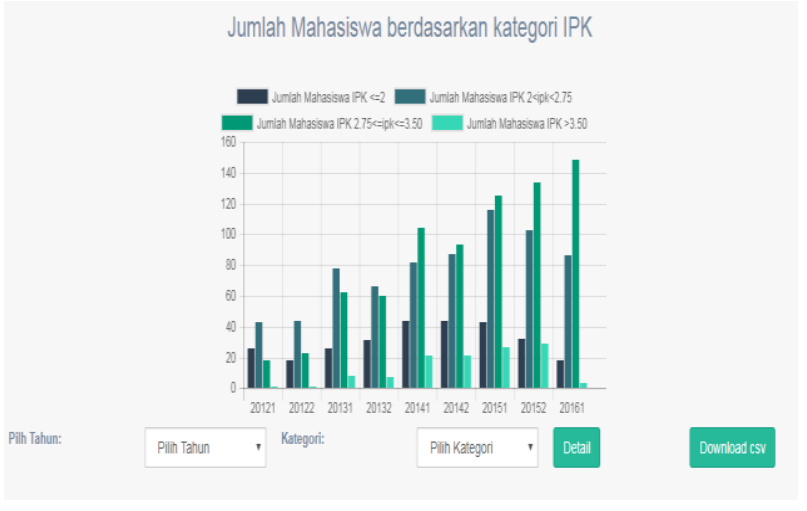

Gambar 11. Halaman informasi selain akreditasi.

Halaman resume penilaian akreditasi dapat dilihat pada Gambar 12 dengan contoh resume penilaian akreditasi standar 3 .

\begin{tabular}{|c|c|}
\hline Kotegeri & Shor \\
\hline 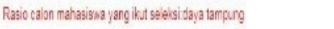 & 4 \\
\hline 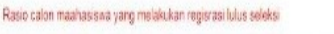 & 384 \\
\hline 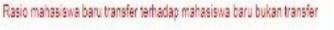 & 4 \\
\hline 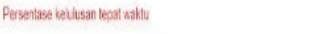 & 0 \\
\hline 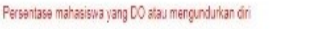 & 0 \\
\hline 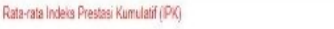 & 4 \\
\hline
\end{tabular}

Gambar 12. Halaman resume penilaian akreditasi.

Pada halaman ini terdapat skor penilaian dari setiap poin standar 3 yang diterapkan, Selain itu, terdapat total skor dari semua kriteria standar 3.

\section{E. Hasil Pengujian Sistem}

Pengujian yang dilakukan pada sistem ini yaitu pengujian metode black box dan pengujian akurasi.

\section{Pengujian black box}

Metode pengujian black box merupakan metode pengujian yang menguji fungsi-fungsi di dalam sistem untuk menentukan apakah fungsi tersebut sudah berjalan yang diharapkan, dan diperoleh hasil bahwa semua (100\%) fungsi yang diinginkan telah sesuai.

2. Pengujian akurasi

Metode pengujian akurasi merupakan metode pengujian dimana apakah output penilaian pada sistem sama dengan teknik perhitungan yang dilakukan secara manual, dan diperoleh hasil bahwa semua output penilaian pada sistem sama dengan perhitungan manual yang telah dilakukan. Contoh pengujian akurasi yang dilakukan adalah rasio calon mahasiswa yang ikut seleksi dibagi daya tampung seperti yang ditunjukkan dalam Tabel V.
TABLE V. Pengujian AKURAsi Contoh Standar 3.

\begin{tabular}{|c|c|}
\hline KPI & $\begin{array}{l}\text { Rasio calon mahasiswa yang ikut seleksi dibagi } \\
\text { daya tampung. }\end{array}$ \\
\hline Perhitungan & Rasio $=\frac{a}{b}$ \\
\hline Keterangan & $\begin{array}{l}\text { - } \begin{array}{l}\mathrm{a}=\text { jumlah calon mahasiswa reguler yang ikut } \\
\text { seleksi selama } 5 \text { tahun akademik terakhir } \\
\mathrm{b}=\text { jumlah daya tampung } 5 \text { tahun akademik } \\
\text { terakhir }\end{array} \\
\end{array}$ \\
\hline Kesimpulan & $\begin{array}{ll}- & \text { sangat baik jika rasio } \geq 5 \text {, maka skor }=4 \text {. } \\
\text { - } & \text { baik dan cukup jika } 1<\text { rasio }<5, \text { maka skor } \\
& =(3+\text { Rasio }) / 2 . \\
\text { - } & \text { kurang dan sangat kurang jika rasio } \leq 1, \text { maka } \\
\text { skor }=2 * \text { Rasio. }\end{array}$ \\
\hline \multicolumn{2}{|c|}{$\begin{array}{l}a=12609 \\
b=472\end{array}$} \\
\hline Rasio & $\begin{array}{l}=12609 / 472 \\
=26.71 \text {, karena rasio }>=5 \text { maka } \\
\text { kesimpulan adalah "sangat baik" } \\
\text { dengan skor }=4 .\end{array}$ \\
\hline
\end{tabular}

Dalam hal ini sistem juga telah mampu menunjukkan kesimpulan dan nilai yang sama.

\section{V.KESIMPULAN DAN SARAN}

Kesimpulan yang didapat dari penelitian Sistem Monitoring Akademik Menggunakan Data Warehouse adalah :

1. Sistem monitoring akademik yang telah dibangun memanfaatkan data warehouse.

2. Pengimplementasian data warehouse pada sistem monitoring akademik dapat mengoptimalkan query yang digunakan untuk memenuhi kebutuhan informasi PSTI.

3. Sistem dibangun dengan data internal SIA dan data eksternal akademik dalam format csv.

4. Sistem dapat dimanfaatkan untuk mendukung proses akreditasi.

5. Sistem monitoring akademik dapat memberikan informasi mengenai mahasiswa, alumni, siswa baru, dosen, dan matakuliah, serta dapat menyajikan informasi persentase, skor, dan kesimpulan berdasarkan teknik perhitungan Buku VI (Matriks Instrumen Penilaian Areditasi BAN-PT).

Saran pengembangan lebih lanjut pada sistem ini adalah dapat menambahkan poin-poin yang bersifat kualitatif yang mengacu pada Buku VI BAN-PT, dapat menambahkan fungsi standar 1, standar 2, standar 6, dan standar 7 yang berpedoman pada standar akreditasi BAN-PT, serta dapat menambahkan pengguna sistem yang bersifat umum.

\section{DAFTAR PUSTAKA}

[1] N. I. Widiastuti dan R. Susanto, "Kajian Sistem Monitoring Dokumen Akreditasi Teknik Informatika UNIKOM, "Jurnal Majalah Ilmiah Unikom, vol. 12, no. 2, 2014.

[2] F. C. Saputro, W. Anggraeni, dan A. Mukhlason, "Pembuatan Dashboard Berbasis Web Sebagai Sarana Evaluasi Diri Berkala Untuk Persiapan Penilaian Akreditasi Berdasarkan Standar Badan Akreditasi 
Nasional Perguruan Tinggi," J. Tek. ITS, vol. 1, no. 1, pp. A397-A402, Sep. 2012.

[3] U. Fadilah, W. W. Winarno, dan A. Amborowati, "Perancangan Data Warehouse Untuk Sistem Akademik STMIK Kadiri Data Warehouse System Design for Academic STMIK Kadiri," Sisfotenika, vol. 6, no. 2, pp. 217-228, 2016.

[4] A. A. Sopingi, E. Utami, "Prototype Executive Information System untuk Mendukung Evaluasi Diri Perguruan Tinggi (Studi Kasus STMIK Duta Bangsa Surakarta)," J. Ilm. DASI, vol. Vol. 16, no. 02, pp. 6674, 2015.

[5] I. Hadi, I. B. K. Widiartha, dan I. W. A. Arimbawa, "Desain dan Implementasi Service Oriented Architecture Pada Sistem Informasi Geografis Pemerintah Kabupaten Lombok Barat," Journal Computer Science Informatics Engineering, vol. 1, no. 1, p. 33, Jan. 2018

[6] R. Parahita, I. B. K. Widiartha, dan A. Zubaidi, "Sistem
Informasi Perhotelan Berbasis Web Service, Studi Kasus Di Pulau Lombok," Journal Computer Science Informatics Engineering, vol. 1, no. 1, p. 46, Jan. 2018.

[7] M. Z. Hamidi, S. E. Anjarwani, dan I. W. A. Arimbawa, "Rancang Bangun Sistem Informasi Praktek Kerja Lapangan Pada Program Studi Teknik Informatika Universitas Mataram Menggunakan Extreme Programming," Journal Computer Science Informatics Engineering, vol. 1, no. 1, p. 11, Jan. 2018.

[8] T. Yulianto, I. Bagus, K. Widiartha, I. Wayan, dan A. Arimbawa, Rancang Bangun Sistem Informasi Geografis Fasilitas Umum Kota Mataram Berbasis Web (Design and Implementation of Web based Geographical Information System of Public Facility in Mataram City). Mataram:Universitas Mataram, 2014.

[9] BAN-PT, Borang $3 A$ Akreditasi Program Studi (S1). 2008.

[10] BAN-PT, Buku 6-Matriks Penilaian Akreditasi Sarjana. Ban-PT, 2008. 